\title{
Women Scientists in Typhus Research During the First Half of the Twentieth Century
}

Jean Lindenmann

\section{Summary}

Several women scientists have contributed to typhus research, which carried an exceptionally high risk of laboratory infection. The work of five of them, Ida Bengtson (1881-1952), Muriel Robertson (1883-1973), Hilda Sikora (1889-1974), Hélène Sparrow (1891-1970) and Clara Nigg (1897-1986), is reviewed and the names of several others are mentioned. The lives of these women seem typical of rickettsiologists and reflect the disasters that befell the world during the first half of the twentieth century.

Keywords: history of typhus; women scientists; Bengtson; Robertson; Sikora; Sparrow; Nigg

\section{Zusammenfassung}

Mehrere Wissenschafterinnen haben Beiträge zur Erforschung des Fleckfiebers geleistet, was mit einem besonders hohen Infektionsrisiko verbunden war. Die Arbeiten von fünf dieser Frauen, Ida Bengtson (1881-1952), Muriel Robertson (1883-1973), Hilda Sikora (1889-1974), Hélène Sparrow (18911970) und Clara Nigg (1897-1986), werden vorgestellt und die Namen anderer erwähnt. Die Lebensläufe dieser Frauen scheinen typisch für Rickettsienforscher zu sein und widerspiegeln die Katastrophen der ersten Hälfte des zwanzigsten Jahrhunderts.

* Acknowledgments: I would like to thank Heinz Arnheiter, Adrian Reuben, Arthur Silverstein, Catherine Thalmann and Monika Wiget for their help.

Jean Lindenmann, Obere Geerenstrasse 34, CH-8044 Gockhausen (jean.lindenmann@access. unizh.ch). 


\section{Introduction}

Typhus, whose "tragic relationship to mankind" has been admirably described ${ }^{1}$, caused immense suffering in the first half of the 20th century. The Balkan Wars, the First World War, the Russian Revolution and the Second World War, each saw a resurgence of this dreaded disease, illustrating the statement that "the history of typhus is the history of human misery"2.

Whereas work by such authors as Brill, Cox, Felix, Nicolle, Prowazek, Ricketts, Rocha Lima, Weigl, Weil, Wolbach and Zinsser is widely acknowledged $^{3}$, it is not always realised that several women scientists worked in this area and made important contributions. The present paper attempts to do justice to these largely forgotten, courageous women. For it must be remembered that working with typhus was dangerous, and many researchers paid with their lives: Ricketts, von Prowazek, Motheau, Bacot, Elisabeth Brandt, Weil, Breinl, not to mention many forgotten victims, like laboratory technicians, nurses, military and civilian doctors. And practically all who worked with typhus sooner or later contracted the disease and were sometimes severely affected.

The five women scientists I wish to present in some detail are arranged according to date of birth. Although all of them also worked in other areas, I am focussing on their contributions to typhus research.

\section{Ida Albertina Bengtson (1881-1952)}

Her name is frequently misspelt "Bengston" ${ }^{4}$, and even the internet version of "Notable Contributions to Medical Research by Public Health Scientists" 5 manages to distort her second given name as "Aleertina".

The daughter of Swedish immigrants was born in Harvard, Nebraska, in 1881. AB degree from the University of Nebraska 1903. Cataloguer in the Library of the U.S. Geological Survey. She entered the University of Chicago to study bacteriology in 1911, gained the MS degree in 1913 and a PhD in 1919. She was a bacteriologist in the Chicago Department of Health in 1915, and 1916 was appointed as the first woman bacteriologist at the Hygienic Laboratory of the U.S. Public Health Service (director Dr George W.

1 Zinsser 1985.

2 Hirsch 1881, 405.

3 Mooser 1946; Wilder 1950; Woodward 1973; Sackmann 1980; Harden 1985.

4 O'Hern 1985.

5 Barry 1960. 
McCoy). After working on the agents of botulism, gas gangrene and trachoma she became a member of the "typhus unit" and for this work she was awarded the Typhus Medal of the American Typhus Commission in 1947. She retired in 1946 and died 1952.

Her first paper in the typhus field ${ }^{6}$ deals with the Weil-Felix reaction, the somewhat disturbing finding that certain Proteus so-called X strains isolated from typhus victims were regularly agglutinated by typhus ${ }^{7}$ convalescent serum. It was soon realised by most workers that no aetiologic relationship linked the X strains with typhus and Ida Bengtson, in the paper which is actually a short review, concluded that, in spite of the analogy with the Widal test for typhoid, the Weil-Felix test did not indicate an aetiologic relationship between Proteus X strains and typhus.

Sixteen years later she published a paper on the cultivation of the agent of Rocky Mountain spotted fever in the chick chorio-allantoic membrane ${ }^{8}$. The technique employed was that first developed by Woodruff and Goodpasture for fowl pox virus ${ }^{9}$, and incidentally, A. M. Woodruff was a woman too. Twenty passages on chick embryos did not change the virulence of the agent for guinea pigs. The presence of typical rickettsiae in cells of the chorioallantoic membrane after many passages lent "support to the view that these organisms are concerned as the causative agent of the disease".

In her next paper ${ }^{10}$ she investigated an improved Maitland type system for the cultivation in vitro of rickettsiae of epidemic and murine typhus, based on the technique of Nigg (also a woman, see below) and Landsteiner. Abundant growth was observed. During the war she developed complement fixation tests for distinguishing the agents of Rocky Mountain spotted fever, murine and epidemic typhus and scrub typhus (Tsutsugamushi, now placed in the genus Orientia $)^{11}$. During her work she contracted typhus ${ }^{12}$. Her last paper, written when still employed at the National Institutes of Health, dealt with the classification of the rickettsiae of Rocky Mountain spotted fever and of murine typhus ${ }^{13}$. In this she did away with the generic name "Dermacentroxenus" proposed by Wolbach. After her retirement, her chapter on the family "Rickettsiaceae" appeared in the sixth edition of the influential "Bergey's Manual of Determinative Bacteriology"14.

6 Bengtson 1919.

7 Fairley 1919.

8 Bengtson/Dyer 1935.

9 Woodruff/Goodpasture 1931.

10 Bengtson 1937.

11 Bengtson 1945a; Bengtson 1945b; Bengtson 1946a; Bengtson 1946b; Bengtson 1946c.

12 O'Hern 1985.

13 Bengtson 1947.

14 Breed/Murray, et al. 1948. 


\section{Muriel Robertson (1883-1973)}

Born the seventh child in a well-to-do family of twelve in Glasgow (1883), Muriel Robertson was at first attracted to music and literature ${ }^{15}$. She had a talent for languages, was fluent in French and German and learned Latin and mathematics from a tutor. While studying for an MA degree, she became interested in zoology and botany. Her first publication on protozoa dates from 1905. With a Carnegie Fellowship, which she held from 1907 to 1910, she worked first in Ceylon (now Sri Lanka) and then in Glasgow on trypanosomes. In 1909 "the young leddy from Glasgow"16 was for two years at the Lister Institute of Preventive Medicine in London under Sir Charles Martin. In 1911 she went to Uganda, where a devastating outbreak of sleeping sickness was raging ${ }^{17}$, to study trypanosomes. In 1914 she returned to the Lister Institute, where, except for a short period during the Second World War, she remained until 1961. She retired to Cambridge, where she died in 1973.

During the First World War she worked for a short while on typhus and contributed two important papers, namely a review of the state that typhus research had reached by the beginning of 1917, and an original article in which she demonstrated that a coccus isolated from cases of typhus in Ireland was not the aetiologic agent of the disease. This work, dictated by wartime necessities, forms only a small part of her scientific output and is only briefly mentioned in her official biography ${ }^{18}$.

Like Hilda Sikora (see below) she was an accomplished draughtswoman. After the war Muriel Robertson had a very distinguished career as a bacteriologist (anaerobic bacteria) and protozoologist (Trypanosoma, Trichomonas). She earned many honours: honorary memberships of the Society for General Microbiology, the British Society for Parasitology and the Section of Comparative Pathology of the Royal Society of Medicine. The pinnacle of her career came with her election in 1947, as a Fellow of the Royal Society, of which she had been critical, "possibly for feminist reasons", as her biographers write ${ }^{19}$. One of the principles guiding her life was the admonition by one of her governesses: "De la tenue, Muriel, de la tenue!"20

15 Bishop/Miles 1974.

16 Chick/Hume, et al. 1971.

17 Blane 2002.

18 Bishop/Miles 1974.

19 Bishop/Miles 1974, 342. The first two women fellows to be elected were Marjorie Stephenson and Kathleen Lonsdale in 1945.

20 Bishop/Miles 1974, 341. 
The review on typhus ${ }^{21}$ that she presented before the Section of Epidemiology and State Medicine of the Royal Society of Medicine on May 25, 1917, gives an excellent summary of American, French and German work. It is remarkable that, in the midst of a terrible war, she was able to appreciate the most recent work done by the enemy $y^{22}$ objectively and place it in a proper perspective. In introducing the lively discussion ${ }^{23}$, Dr Brownlee thanked "Miss Robertson personally for the trouble and care with which she has synopsized and discussed the work on typhus fever which has been carried out during the last few years".

The original contribution ${ }^{24}$ deals with a coccus isolated by a certain Dr Penfold from the urine and blood of typhus victims in Belfast. Muriel Robertson argued that if the coccus was the aetiologic agent, a vaccine made from it should be able to protect monkeys against the subsequent inoculation of virulent blood from authentic typhus cases. No such protection was seen, and her conclusion was that "no evidence was obtained of a causal connection between the coccus" and typhus fever.

\section{Hilda Sikora (1889-1974)}

The daughter of an Austrian explorer, Hilda Sikora was born in 1889 in what was then called Tananarive, now Antananarivo (Madagascar). She had no formal schooling, but as an autodidact reached a high level of entomological competence. Hilda Sikora died in Vienna in 1974. She is described as a very unconventional, cultivated, multilingual and exceedingly modest person ${ }^{25}$.

After a stay in Vienna she was employed from 1915 on as an illustrator and draughtswoman of arthropod anatomy at the Institute for Tropical Medicine (Tropeninstitut) in Hamburg (Germany). Because of the recent recognition of the louse as the vector of typhus and the emergence of typhus on the eastern front Stanislaus von Prowazek suggested that she study the anatomy and biology of body and head lice, about which only little was known. She soon became a leading expert in this field and published a beautifully illustrated monograph ${ }^{26}$ (fig. 1).

21 Robertson 1917a.

22 Rocha Lima 1916.

23 Robertson 1917a.

24 Robertson $1917 b$.

25 Anonymous 1970.

26 Sikora 1916a. 


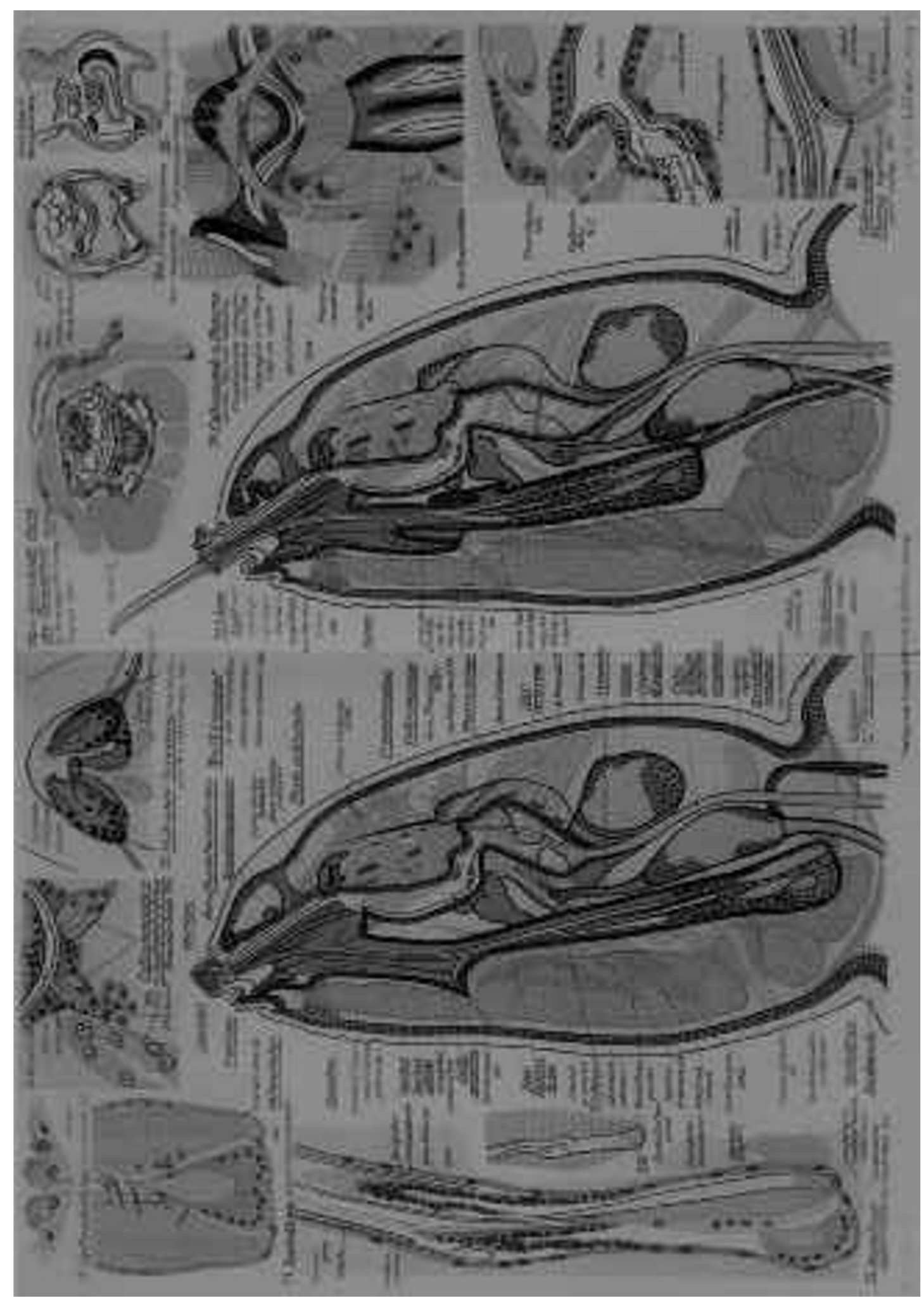

Fig. 1. Drawings of louse anatomy by Hilda Sikora (1916a). 
Hilda Sikora devised "cages" for feeding lice on human volunteers (and more particularly on herself) and developed a technique for intracoelomal injection ${ }^{27}$. In collaboration with Henrique da Rocha Lima $^{28}$, a Brasilian scientist also working in Hamburg, she became thoroughly familiar with various rickettsiae. In the course of this work she contracted typhus ${ }^{29}$. She fed hundreds of lice on herself until she developed an allergic reaction. In numerous communications she did not hesitate to contradict views, expressed by otherwise well-established scientists, on questions of louse anatomy, physiology and on rickettsiae ${ }^{30}$. During the Second World War, in 1940 she moved to Berlin and worked at the Institute of Hygiene (Hygiene-Institut) under Heinz Zeiss and resumed feeding lice ${ }^{31}$. She left the institute in 1945 and earned her living as a painter. In 1957 she was temporarily employed at the Zoological Institute in Bonn ${ }^{32}$. From 1960 on she lived in Vienna, where she died in 1974. Hilda Sikora is considered one of the more original entomologists of the first half of the 20th century ${ }^{33}$ and is credited with having independently identified the "mycetoma" of arthropods, organs containing symbiotic microorganisms ${ }^{34}$.

\section{Hélène Sparrow (1891-1970)}

Hélène Sparrow was born 1891 in Boguslav near Kiev in tsarist Russia, now the Ukraine ${ }^{35}$. Her maternal grandfather was a doctor. She studied medicine in Kiev from 1909 to 1915 and became attached to the medical services of the tsarist Russian army. From 1918 to 1920 she worked as a bacteriologist in Kiev. In 1920 she left Kiev with the Polish army, which had briefly occupied Kiev, and settled in Warsaw (Poland) at the Institute of Hygiene from 1920 to 1933, where she collaborated with Rudolf Weigl. During this time Hélène Sparrow obtained League of Nations fellowships to visit the Pasteur Institutes of Lille, Brussels and Tunis, and the Hygiene Institute of Strasbourg. In 1931, together with Charles Nicolle (Nobel Prize 1928), she studied endemic typhus in Mexico and Guatemala and visited Hermann Mooser, who

27 Sikora 1923.

28 Rocha Lima/Sikora 1925.

29 Weidner 1967.

30 Sikora 1915; Sikora 1916b; Sikora 1917a; Sikora 1917b; Sikora 1920; Sikora 1921; Sikora 1924; Sikora 1943; Sikora 1944.

31 Sikora 1944.

32 Weidner 1967.

33 Anonymous 1970.

34 Internet 2003a.

35 Internet 2004. 
had been the first to show biologic differences between classical (epidemic) and murine (endemic) typhus ${ }^{36}$. She obtained French citizenship in 1933. From 1933 until her retirement in 1960 she was laboratory chief at the Pasteur Institute in Tunis. During the Second World War, she helped French and Polish refugees in Tunis. She is mentioned in André Gide's diary when her apartment was bombed ${ }^{37}$. She was married twice. Hélène Sparrow died in 1970 in Corsica (France) and was survived by a daughter. She is not on record as having obtained the "Légion d'honneur".

To understand her first independent publication on typhus from Warsaw shortly after the First World War one has to realise that the only experimental animal affordable at that time in Poland for typhus work was the guinea pig and that the only sign of infection this animal showed was a transient elevation of its rectal temperature. Now guinea pigs, particularly when held under the conditions prevailing in Poland during the conflicts that exploded in the aftermath of the First World War, are apt to contract all sorts of intercurrent diseases that result in fever of varying aetiology. When typhus is passed from man to guinea pig, and then serially from guinea pig to guinea pig over many months, there is always the possibility that one is passaging an agent that has no longer anything to do with typhus. It is therefore essential to convince oneself that the agent one is working with is the real aetiologic agent of typhus. Occasionally, as happened to Weigl and to many other typhus workers, a laboratory accident, whereby one of the workers gets inadvertently infected with the passaged agent (and sometimes dies), proves beyond doubt that typhus is still there. The young Hélène Sparrow, rather than waiting for such an accident to occur, decided to inoculate herself purposefully with material taken from the twenty-second serial guinea pig passage, to see if she was still dealing with the agent of typhus. The inoculation was done on December 25, 1921. And she did develop typhus, with all the required symptoms, and fortunately survived ${ }^{38}$.

During her work in Tunis, in collaboration with Nicolle, she attempted to vaccinate people against typhus by inoculating them with minute doses of infectious material, using various routes ${ }^{39}$. For these experiments Hélène Sparrow enlisted volunteers. Some were inmates of mental hospitals, but one should remember that at that time fever therapy of progressive paralysis of the insane was a recognised treatment, frequently achieved by inoculation

36 Mooser 1928.

37 Kempowski 1993, 45, 271.

38 Sparrow 1922.

39 Sparrow/Lumbruso 1929; Sparrow 1933; Sparrow 1935a; Sparrow 1935b; Sparrow/Mareschal 1938. 
of malaria. Thus inoculation of murine typhus, less pathogenic than classical epidemic typhus, and less problematic than malaria, could be seen as a form of fever therapy. In 1940 she developed a mouse lung inoculation technique ${ }^{40}$ which formed the basis for the Giroud killed vaccine used for the vaccination of French prisoners of war in German POW camps ${ }^{41}$.

In a paper in honour of Mooser's 70th birthday she reported an observation which shows her great skill as a microscopist. Hélène Sparrow had been able, in 1938, to recognise, on purely morphological grounds, the simultaneous presence of two different, very similar microorganisms within the same louse: the agent of Mediterranean spotted fever and that of Trench fever, both at that time classified as rickettsiae, both difficult to stain and both of a size near the limit of resolution of the light microscope. In the course of this work she contracted Trench fever, probably involuntarily $y^{42}$.

\section{Clara Ida Nigg (1897-1986)}

Clara Nigg was born in 1897 in Waco, Nebraska ${ }^{43}$, and studied at the University of Kansas, receiving her MA in 1921 and a $\mathrm{PhD}$ in 1929 for her thesis "Studies on Isohemagglutination" ${ }^{44}$. After work in bacteriology at a public health laboratory and at St. Bartholomew Hospital in New York she obtained a position as a bacteriologist at the Health Department of Minnesota (1923). From 1923 to 1926 and again from 1927 to 1929 she was an instructor in bacteriology at the University of Kansas. From 1926 to 1927 she was in charge of serology at the Queen's Hospital in Honolulu, Hawaii. Clara Nigg joined the Rockefeller Institute to work with Karl Landsteiner (Nobel Prize 1930) from 1929 to 1937. From 1937 to 1941 she was back in Minnesota and acted as an instructor at the Medical School of the University of Minnesota. From 1941 to 1951 she headed the virus laboratory of the Squibb Institute for Medical Research, New Brunswick, N. J. During the war, from 1943 to 1944, she worked for the chemical warfare unit at Fort Detrick, Maryland, and remained a consultant for research in the Department of Defense 1944-1951. In 1947 she thanked Dr. Peyton Rous (who was to receive the Nobel Prize in 1966) for his contribution of a bibliographic sketch of Karl Landsteiner ${ }^{45}$. In

40 Durand/Sparrow 1940.

41 Giroud 1947.

42 Sparrow 1961.

43 Speiser/Smekal 1990.

44 Internet 2003b.

45 Nigg 1947. 
1952 she became head of the bacteriological section of the Naval Biological Laboratory, School of Public Health, University of California in Berkeley, from where her last paper appeared in $1963^{46}$.

In her work with Landsteiner, the aim was to develop a method for in vitro cultivation of rickettsiae on an inert medium, thus proving the bacterial nature of the organism. One of her colleagues during that time wrote: “... the year after year effort with Clara Nigg (whose unselfish, devoted work deserves the highest praise. During the course of the work she contracted typhus fever and was ill for many months!) ..."47. Although cultivation of typhus rickettsiae in the absence of a living substrate proved impossible, an ingenious application of Mooser's findings allowed the elaboration of a suitable tissue culture system ${ }^{48}$. Increasing familiarity with the organisms as seen in properly stained microscopic preparations convinced her that, despite failure to grow on inert media, rickettsiae must be bacteria. Failure to grow on inert media was one of the criteria used to separate the so-called "filterable viruses" from bacteria. Clara Nigg concluded that inability to grow on a non-living substrate could not be used as an argument against the bacterial nature of an agent. Indeed, innumerable bacteria exist that, to this day, cannot be grown in vitro.

Clara Nigg had begun her career by an investigation of blood groups of American Indians ${ }^{49}$. She then switched to the typhus work already mentioned. As a side-line she described an infectious agent present in mouse colonies, referred to as "Nigg agent" 50 . She also prepared antigens for the diagnosis of influenza and lymphogranuloma ${ }^{51}$. Later she concentrated her efforts on melioidosis, a disease confronting American forces in Southeast Asia and potentially a biological warfare agent ${ }^{52}$. There exists a tape record of an interview by Sally Smith Hughes with Clara Nigg from 1982 at the Bancroft Library, University of California. The transcript is very interesting ${ }^{53}$. The 85-year-old Clara Nigg vividly remembers her work, done half a century earlier, with Landsteiner, and the fact that she was allowed to be first author of their joint papers: "Clara Nigg and Landsteiner. That's most unusual. Most unusual", she said in the interview. She died in $1986^{54}$.

46 Nigg 1963.

47 Speiser/Smekal 1990.

48 Nigg/Landsteiner 1930; Nigg/Landsteiner 1931/32; Nigg 1935a; Nigg 1935b; Nigg 1936.

49 Nigg 1926.

50 Nigg 1942; Nigg/Eaton 1944.

$51 \mathrm{Nigg/Crowley,} \mathrm{et} \mathrm{al.} \mathrm{1940;} \mathrm{Nigg/Hilleman,} \mathrm{et} \mathrm{al.} 1946$.

52 Nigg/Heckly, et al. 1955; Nigg/Ruch, et al. 1956; Nigg/Johnston 1961; Nigg 1963.

53 Hughes 1982.

54 Silverstein 2004. 


\section{Other women scientists engaged in typhus research}

Reading through typhus literature, I have come across several names on which I have no biographical data and which I will briefly list alphabetically, in the hope that someone else will shed light on the lives of these women: Afanassiewa, A. ${ }^{55}$; Barikina, O. ${ }^{56}$; Brandt, Elisabeth ${ }^{57}$; Crodel, Beatrice ${ }^{58}$; Dosser, E. M. ${ }^{59}$; Schlote, Annemarie ${ }^{60}$; Serebrennaja, A. I. ${ }^{61}$

\section{Discussion}

Typhus research, indeed the entire field of rickettsiology, occupies a very special position in microbiology during the first half of the 20th century ${ }^{62}$. The techniques had to be borrowed from four overlapping disciplines, i.e. from bacteriology (staining, microscopy), parasitology (arthropod vectors), pathology (animal inoculation, histology) and what eventually became known as virology (chick embryo technique, tissue culture). In addition, particular skills were required, such as rectal temperature measurements in guinea pigs, injections by the rectal or intracoelomal route into lice, feeding of lice on human subjects, employing unusual stains and infection of the yolk sac of the developing chick embryo rather than the chorio-allantoic or amniotic membrane. One should also bear in mind that working with these agents carried an unprecedentedly high risk of laboratory infection.

The five women scientists whose typhus work I have summarised form a heterogeneous group. Except for Clara Nigg they were drawn to typhus research not by choice but by wartime necessities. All seem to have come from upper middle-class families and to have had understanding parents. The case of Hilda Sikora is rather unique, in that she had no formal, even elementary schooling and was partly taught by her father, who was an ex-

55 Afanassiewa/Tretjak 1933.

56 Barikin/Kompanejez, et al. 1927; Barykin/Zacharoff, et al. 1929.

57 Kuczynski/Blühbaum, et al. 1927.

58 Haagen/Crodel 1944a; Haagen/Crodel 1944b. Crodel was the lab technician of Eugen Haagen, director of the Hygiene Institute of the "Reichs"-University of Strasbourg during the German occupation (1941-1944). Haagen and Crodel experimented with dried typhus vaccines based on murine typhus. The experimental subjects were inmates of the concentration camp of Struthof/Natzweiler. Haagen was tried as a war criminal in a French court in Metz in 1952 (Weindling 2000). He was released in 1955, married Crodel and obtained a position in Germany as attested by two publications: Haagen/Haagen-Crodel 1957; Haagen/Haagen-Crodel 1958.

59 Kuteischikow/Dosser, et al. 1933.

60 Schlote 1947.

61 Grünfeld/Serebrjannaja, et al. 1933; Serebrennaja/Grünfeld, et al. 1933.

62 Harden 1990; Weindling 1995; Lindenmann 2002. 
plorer. Four of them were single - obviously, it was not easy for them to reconcile their work with some sort of family life. It comes as a surprise that only one of them, Hélène Sparrow, was medically qualified, because one might think that medicine was, for women, the easiest way of entering science, encountering the fewest objections from parents or society. All five were fortunate in being accepted by male colleagues of high merit: Ida Bengtson by George W. McCloy, Muriel Robertson by Sir Charles Martin, Hilda Sikora by Stanislaus von Prowazek, Hélène Sparrow by Charles Nicolle, and Clara Nigg by Karl Landsteiner. In spite of the dangers surrounding their work (for all of them, except for Muriel Robertson, there is evidence that they contracted typhus) they reached respectable ages of between 71 and 90 years. What seems to be typical of these women were curiosity, determination, talents both artistic and technical, courage and a sense of their own worth coupled with modesty.

Sex discrimination does not seem to have played an important role. In the interview of Clara Nigg she was specifically asked: "Did you ever have any feeling that you were at a disadvantage because you were a woman?" Nigg: "No." Interviewer: "You don't think that entered in any of the thinking?" Nigg: "No." ${ }^{63}$ Nevertheless, if one were to select at random five male scientists of similar achievements and from the same period, one would expect to find one or the other in the position of a tenured professorship. This probably is to be explained by the fact that these women found convenient niches in institutions that were not directly linked with universities: the Laboratory of Public Health - NIH (Bengtson), the Lister Institute (Robertson), the Tropeninstitut Hamburg (Sikora), the Pasteur Institute Tunis (Sparrow), the Rockefeller Institute, later the Naval Biological Laboratory (Nigg). That the biographies of these women do not offer examples of blatant sex discrimination does not mean that there was none. These women scientists simply chose (had to choose) institutions that were more open to women than were the traditional academic departments.

A fairly straightforward career was that of Ida Bengtson, even though she entered science relatively late in life and obtained her $\mathrm{PhD}$ at the age of 38 . She was professionally well sheltered within what became the National Institutes of Health and had the convenient possibility of publishing her work in the Public Health Reports. Her major contribution to rickettsiology was her development of complement fixation tests for distinguishing various species. This is evidenced by her work being extensively quoted in Rivers' important textbook of 1948, Viral and Rickettsial Infections of Man ${ }^{64}$, and her collabo- 
ration to Bergey's Manual ${ }^{65}$. The most brilliant career was that of Muriel Robertson. Her contact with typhus research was only brief, but in it one already finds the qualities that made her exceptional: the ability to critically evaluate a large field within a short time and the readiness to accept (and publish) negative findings, thereby early debunking one of the innumerable purported aetiologic agents of typhus. Hilda Sikora's life was quite unusual. Without any formal training she reached proficiency within a highly specialised field of entomology (fig. 1). The major part of her scientific life was spent within the Tropeninstitut in Hamburg. She suffered from the vicissitudes of the 20th century and was forced, after the Second World War, to eke out a living by flower painting. Hélène Sparrow also suffered from the turmoil which twice engulfed Europe. Born in tsarist Russia, she was Polish and later French, and her haven was to be the Pasteur Institute in Tunis, where she significantly contributed to the development of immunisation procedures. The story of Clara Nigg is interesting. Like that of the others, her scientific career was deeply influenced by wartime obligations, but in her case this did not concern typhus. During World War II she was "drafted", as she said, to work on some aspect of bacteriological warfare about which, even at the distance of 40 years, she felt unable to speak ${ }^{66}$. Her typhus work was inspired by Karl Landsteiner and stems from his old preoccupation with the conditions which might allow exacting microorganisms to be grown in vitro ${ }^{67}$. She correctly concluded that inability to grow an organism in vitro did not disqualify it from being classified as a bacterium. Her work (like that of Bengtson) is quoted in Rivers' 1948 textbook Viral and Rickettsial Infections of $\mathrm{Man}^{68}$.

Each one of these women would deserve a full-length biography, and each of these biographies would mirror the devastations of one of the bloodiest half centuries within human memory.

\section{Bibliography}

Afanassiewa, A./Tretjak, «Ueber Flecktyphusvirusträger», Zentralblatt für Bakteriologie I Originale 130 (1933) 123-128

Anonymous, «Hilda Sikora», Angewandte Parasitologie 11 (1970) 63

Barikin, W./A. Kompanejez, et al., «Studien über den Flecktyphus. Der experimentelle Flecktyphus beim Meerschweinchen», Zbl. Bakt. I Orig. 102 (1927) 329-338

65 Breed/Murray, et al. 1948.

66 Hughes 1982.

67 Landsteiner/Berliner 1913. In this paper Landsteiner had reported successful passage of fowl plague virus in a culture fluid containing fresh blood and had concluded that this was due to the presence of living cells.

68 Rivers 1948. Nigg is quoted as extensively as Nicolle. 
Barry, J., "Notable contributions to medical research by Public Health Service scientists. A bibliography to 1940", Public Health Service Publication No. 752 (1960) VIII, 61

Barykin, W./A. Zacharoff, et al., «Untersuchungen über das Fleckfieber. II. Mitteilung: Das Fleckfieber bei Kleiderläusen», Zbl. Bakt. I Orig. 112 (1929) 25-32

Bengtson, I. A., "The Weil-Felix reaction as a laboratory test in the diagnosis of typhus fever", Public Health Reports 34 (1919) 2446-2450

- "Cultivation of Rickettsiae of endemic (murine) and epidemic (European) typhus fever in vitro", Publ. Hlth Rep. 52 (1937) 1336-1340

- "Applications of the complement-fixation test in the study of rickettsial diseases", American Journal of Public Health 35 (1945a) 701-707

- "Apparent serological heterogeneity among strains of Tsutsugamushi disease (scrub typhus)", Publ. Hlth Rep. 60 (1945b) 1483-1488

- "Serological relationships in the epidemic-endemic typhus group as determined by complement fixation", Publ. Hlth Rep. 61 (1946a) 1379-1385

- "Complement fixation in Tsutsugamushi disease (scrub typhus)", Publ. Hlth Rep. 61 (1946b) $895-900$

- "A serological study of 37 cases of Tsutsugamushi disease (scrub typhus) occurring in Burma and the Philippine Islands", Publ. Hlth Rep. 61 (1946c) 887-894

- "Classification of the Rickettsiae of Rocky Mountain Spotted Fever and of Endemic (Murine) Typhus", Journal of Bacteriology 53 (1947) 325-327

- /R. E. Dyer, "Cultivation of the virus of Rocky Mountain Spotted Fever in the developing chick embryo", Publ. Hlth Rep. 50 (1935) 1489-1498

Bishop, A., FRS/S. A. Miles, FRS, "Muriel Robertson 1883-1973", Biographical Memoirs of Fellows of the Royal Society 20 (1974) 317-347

Blane, D., Something out of Africa. University of Glasgow (2002) http://www.gla.ac.uk:443/ avenue/31/africa3.html

Breed, R. S./E. G. D. Murray, et al., Bergey's Manual of Determinative Bacteriology (Baltimore 1948)

Chick, H./M. Hume, et al., War on Disease. A history of the Lister Institute (London 1971)

Durand, P./H. Sparrow, «Inoculation pulmonaire des virus typhiques et boutonneux», Comptes Rendus de l'Académie des Sciences 210 (1940) 420-422

Fairley, N. H., "The laboratory diagnosis of typhus fever. Further observations on the value and on the significance of the Weil-Felix reaction", Journal of Hygiene 18 (1919) 203-216

Giroud, P., "Vaccination against typhus", in: J. Hamburger, Medical Research in France during the War (1939-1945) (Paris 1947) 33-37

Grünfeld, A. A./A. I. Serebrennaja, et al., «Experimentelle Studien über das Flecktyphusvirus», Zbl. Bakt. I Orig. 129 (1933) 56-69

Haagen, E./B. Crodel, «Versuche mit einem neuen getrockneten Fleckfieberimpfstoff», $Z b l$. Bakt. I Orig. 151 (1944a) 307-311

- /B. Crodel, «Versuche mit einem neuen getrockneten Fleckfieberimpfstoff. II. Mitteilung», Zbl. Bakt. I Orig. 151 (1944b) 369-373

- /B. Haagen-Crodel, «Über das Vorkommen sogenannter cytopathogener Effekte in normalen Zellkulturen», Zeitschrift für Hygiene und Infektionskrankheiten 144 (1957) 181-201

- /B. Haagen-Crodel, «Über das Verhalten von Tuberkelbazillen in der Zellkultur», Zbl. Bakt. I Orig. $172(7 / 8)(1958) 525-550$

Harden, V.A.,"Rocky Mountain spotted fever research and the development of the insect vector theory, 1900-1930", Bulletin of the History of Medicine 59 (1985) 449-466

- Rocky Mountain Spotted fever. History of a twentieth-century disease (Baltimore 1990)

Hirsch, A., «XI. Typhus. (Typhus exanthematicus, Petechialfieber)», in: A. Hirsch, Die allgemeinen acuten Infectionskrankheiten vom historisch-geographischen Standpunkte und mit besonderer Berücksichtigung der Aetiologie 1 (Stuttgart 1881) 385-417

Hughes, S. S., Clara Nigg, Ph.D. (b. 1897), Bancroft Library, transcript of interview (1982)

Internet, «Bakterienlicht und Wurzelpilz-Endosymbiosen in Forschung und Geschichte», IV. Symbioseforschung in der ersten Hälfte des 20. Jahrhunderts (2003a) http://www.ruhruni-bochum.de/malakow/aust/bak4.htm

Internet, Doctorates conferred in the Sciences by American Universities 1928-1929 (2003b) http://www.nap.edu/openbook/ARC000020/html/1-46.htm 
Internet, Hélène Sparrow (1891-1970), I. P. Archives, Paris, Institut Pasteur (2004) http://www. pasteur.fr/infosci/archives/spa0.html

Kempowski, W., Das Echolot. Ein kollektives Tagebuch Januar und Februar 1943 (München 1993)

Kuczynski, M. H./W. Blühbaum, et al., Der Erreger des Fleck- und Felsenfiebers (Berlin 1927)

Kuteischikow, A./E. M. Dosser, et al., «Der experimentelle symptomlose Flecktyphus beim gesunden und unempfänglichen Menschen», Zbl. Bakt. I Orig. 129 (1933) 262-265

Landsteiner, K./M. Berliner, «Ueber die Kultivierung des Virus der Hühnerpest», Zbl. Bakt. I Orig. 67 (1913) 165-168

Lindenmann, J., "Typhus vaccine developments from the First to the Second World War. (On Paul Weindling's 'Between Bacteriology and Virology ...')", History and Philosophy of Life Sciences 24 (2002) 467-485

Mooser, H., "Reaction of Guinea-Pigs to Mexican typhus (Tabardillo): Preliminary note on bacteriological observations", Journal of the American Medical Association 91 (1928) 19-20

- "Twenty years of research in Typhus fever", Schweizerische Medizinische Wochenschrift 76 (1946) 877-882

Nigg, C., "A study of the blood groups among the American Indians", Journal of Immunology 11 (1926) 319-322

- "On the preservation of typhus fever Rickettsiae in cultures", Journal of experimental Medicine 61 (1935a) 17-26

- "On the presence of typhus virus in wild rats in New York City", J. Inf. Dis. 57 (1935b) 252-254

- "Studies on culture strains of European and murine typhus", J. Exp. Med. 63 (1936) 341-351

- "An unidentified virus which produces pneumonia and systemic infection in mice", Science 95 (1942) 49-50

- Dear Dr. Rous, Rous papers, American Philosophical Society (Philadelphia 1947)

- "Serologic studies on subclinical melioidosis", J. Immunol. 91 (1963) 18-28

- IJ. H. Crowley, et al., "On the use of chick embryo cultures of influenza virus in complement fixation tests", Science 91 (1940) 603-604

- /M. D. Eaton, "Isolation from normal mice of a pneumotropic virus which forms elementary bodies", J. Exp. Med. 79 (1944) 497-510

- /R. J. Heckly, et al., "Toxin produced by Malleomyces pseudomallei", Proceedings of the Society for experimental Biology and Medicine 89 (1955) 17-20

- /M. R. Hilleman, et al., "Studies on lymphogranuloma complement fixing antigens. I. Enhancement by phenol or boiling", J. Immunol. 53 (1946) 259-268

- /M. M. Johnston, "Complement fixation test in experimental clinical and subclinical melioidosis", J. Bact. 82 (1961) 159-168

- /K.Landsteiner, "Growth of rickettsia of typhus fever (Mexican type) in the presence of living tissue”, Proc. Soc. Exp. Biol. Med. 28 (1930) 3-5

- /K. Landsteiner, "Note on the cultivation of the typhus fever Rickettsia", Proc. Soc. Exp. Biol. Med. 29 (1931/32) 1291

- IJ. Ruch, et al., "Enhancement of virulence of Malleomyces pseudomallei", J. Bact. 71 (1956) $530-541$

O'Hern, E. M., Profiles of Pioneer Women Scientists (Washington 1985)

Rivers, T. M. (editor), Viral and Rickettsial Infections of Man (Philadelphia/London/Montreal 1948)

Robertson, M., "Recent researches into the aetiology of typhus", Proceedings of the Royal Society of Medicine 10 (part 2) (1917a) 95-110 (with comment 111-118)

- "Typhus fever: an experiment on vaccination with a coccus derived from human cases", Journal of Pathology and Bacteriology 21 (1917b) 173-183

Rocha Lima, H. da, «Zur Aetiologie des Fleckfiebers. Vorläufige Mitteilung», Berliner klinische Wochenschrift 53 (1916) 567-569

- /H. Sikora, «Methoden zur Untersuchung von Läusen als Infektionsträger», in: E. Abderhalden, Handbuch der biologischen Arbeitsmethoden 12, Teil 1 (Berlin/Wien 1925) 769-814

Sackmann, W., «Fleckfieber und Fleckfieberforschung zur Zeit des Ersten Weltkriegs. Zum Gedenken an Henrique da Rocha Lima (1879-1956)», Gesnerus 37 (1980) 113-132

Schlote, A., «Abtötung von Fleckfieber-Rickettsien durch einige Wasch- und Desinfektionsmittel», Zbl. Bakt. I Orig. 123 (1947) 414-419 
Serebrennaja, A. I./A. A. Grünfeld, et al., «Experimentelle Studien über das Flecktyphusvirus. II. Mitteilung: Experimenteller Flecktyphus bei Zieseln», Zbl. Bakt. I Orig. 129 (1933) 254-262

Sikora, H., «Bemerkungen zu der Arbeit: «Zur Bekämpfung der Kleiderläuse` von Dr. A. Zucker in Heft 4, Bd. 76 dieser Zeitschrift», Zbl. Bakt. I Orig. 77 (1915) 163-164

- «Beiträge zur Anatomie, Physiologie und Biologie der Kleiderlaus (Pediculus vestimenti Nitzsch). I. Anatomie des Verdauungstraktes», Beihefte zum Archiv für Schiffs- u. Tropenhygiene 20 (1916a) 1-76

- «Bemerkungen zur Arbeit von Prof. Kisskalt: ¿Zur mikroskopischen Anatomie von 'Ped. vestimentorum'> in Bd. 77, Heft 4 dieser Zeitschrift», Zbl. Bakt. I Orig. 78 (1916b) 159

- «Ueber Anpassung der Läuse an ihre Umgebung», Arch.f. Schiffs- u. Tropenhyg. 21 (1917a) 172

- «Zur Kleiderlaus-Kopflausfrage. Vorläufige Mitteilung», Arch. f. Schiffs- u. Tropenhyg. 21 (1917b) 275-284

- «Beobachtungen an Rickettsien, besonders zur Unterscheidung der $R$. prowazeki von R. pediculi», Arch. f. Schiffs- u. Tropenhyg. 24 (1920) 347-453

- «Ueber die Züchtung der Rickettsia pediculi», Arch. f. Schiffs- u. Tropenhyg. 25 (1921) 123-124

- «Beitrag zur Kenntnis der Rickettsia Prowazeki», Zbl. Bakt. I Orig. 89 (1923) 271-272

- «Der gegenwärtige Stand der Rickettsiaforschung». Bemerkungen zu der gleichnamigen Arbeit von Weigl in Jg. 3, Nr. 35, S. 1590 u. Nr. 36, S. 1636 dieser Wochenschrift», Klinische Wochenschrift 3 (1924) 2008-2009

- «Zur Morphologie der Rickettsien», Z. Hyg. Inf. Kr. 124 (1943) 250-270

- «Meine Erfahrungen bei der Läusezucht», Z. Hyg. Inf. Kr. 125 (1944) 541-552

Silverstein, A., Re Clara Nigg (Personal communication 2004)

Sparrow, H., «Beitrag zur Erforschung des Fleckfiebervirus», Medizinische Klinik 18 (1922) 1155

- «L'épreuve d'immunisation croisée entre deux virus typhiques: virus historique européen et virus murin mexicain», Archives de l'Institut Pasteur de Tunis 22 (1933) 21

- «Essais d'immunisation avec le virus murin I de Tunis, introduit par la voie nasale», C. $R$. Acad. Sci. 201 (1935a) 1441

- «Essais de vaccination avec les rickettsias virus murin I de Tunis», C. R. Acad. Sci. 201 (1935b) 1524

- «Sur une souche de Rickettsia quintana isolée en Tunisie», Pathologia et Microbiologia 24 (Suppl.) (1961) 140-148

- /U. Lumbruso, «Inoculation du typhus exanthématique par voie nasale et conjonctivale», Arch. Inst. Pasteur Tunis 18 (1929) 1

- /P. Mareschal, «Essais d'immunisation de l'homme par voie oculaire avec les rickettsies du virus murin 1 de Tunisie», Bulletin de l'Académie de Médecine Paris $1193^{\mathrm{e}}$ série (1938) 140-145

Speiser, P./F. G. Smekal, Karl Landsteiner. Entdecker der Blutgruppen und Pionier der Immunologie. Biographie eines Nobelpreisträgers aus der Wiener Medizinischen Schule (Berlin 1990)

Weidner, H., Geschichte der Entomologie in Hamburg (Hamburg/Cram 1967)

Weindling, P., "Between bacteriology and virology: the development of typhus vaccines between the First and Second World Wars", History and Philosophy of the Life Sciences 17 (1995) 81-90

- Epidemics and Genocide in Eastern Europe 1890-1945 (Oxford/New York 2000)

Wilder, R. M., “The rickettsial diseases: discovery and conquest”, Archives of Pathology 49 (1950) 479-489

Woodruff, A. M./E. W. Goodpasture, "The susceptibility of the chorio-allantoic membrane of chick embryos to infection with the fowl-pox virus", American Journal of Pathology 7 (1931) 209-222

Woodward, T. E., "A historical account of the rickettsial diseases with a discussion of unsolved problems", J. Infect. Dis. 127 (1973) 583-594

Zinsser, H., Rats, Lice \& History (London 1985) 